\title{
Nadine Henrard, Les figures du bourgeois dans le "Roman en prose de Guillaume d'Orange"
}

\section{Mariagrazia Ricci}

\section{(2) OpenEdition}

1 Journals

\section{Édition électronique}

URL : http://journals.openedition.org/studifrancesi/7491

DOI : 10.4000/studifrancesi.7491

ISSN : 2421-5856

Éditeur

Rosenberg \& Sellier

\section{Édition imprimée}

Date de publication : 1 décembre 2009

Pagination : 606

ISSN : 0039-2944

\section{Référence électronique}

Mariagrazia Ricci, « Nadine Henrard, Les figures du bourgeois dans le "Roman en prose de Guillaume d'Orange" », Studi Francesi [En ligne], 159 (LIII | III) | 2009, mis en ligne le 30 novembre 2015, consulté le 09 janvier 2021. URL : http://journals.openedition.org/studifrancesi/7491 ; DOI : https://doi.org/ 10.4000/studifrancesi.7491

Ce document a été généré automatiquement le 9 janvier 2021.

\section{(c) 9 (i) $\Theta$}

Studi Francesi è distribuita con Licenza Creative Commons Attribuzione - Non commerciale - Non opere derivate 4.0 Internazionale. 


\title{
Nadine Henrard, Les figures $d u$ bourgeois dans le "Roman en prose de Guillaume d'Orange"
}

\author{
Mariagrazia Ricci
}

\section{RÉFÉRENCE}

NADINE HENRARD, Les figures du bourgeois dans le "Roman en prose de Guillaume d'Orange", dans Autour du XV siècle. Journées d'études en l'honneur d'Alberto Vàrvaro, cit pp. 63-77.

1 S'inspirant à l'étude magistrale de François Suard (Paris, Champion, 1979), N.H. étudie la présence de la bourgeoisie dans le Guillaume d'Orange en prose. Le prosateur anonyme ne s'est évidemment pas limité à un travail de simple dérimage de l'ancien poème, mais l'a modernisé afin d'atteindre un public élargi: c'est ainsi que les thématiques urbaines entrent de manière importante dans le roman.

2 En premier lieu, l'A. constate un flottement du mot «bourgeoisie», qui peut se référer aux habitants de la ville mais aussi aux riches marchands, ce qui témoigne d'une évolution en même temps sémantique et sociale du substantif. Ensuite, N.H. s'attache à quelques épisodes qui offrent un portrait du «bourgeois»: porteur de valeurs nouvelles, différentes de celles de l'aristocratie mais toujours positives, et promoteur d'une image valorisée de la ville, sur le plan tant moral qu'économique. 